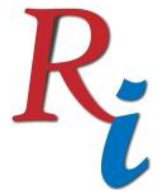

Asia Proceedings of Social Sciences

(APSS)

www.readersinsight.net/APSS

\title{
How Service Quality Affects Customer Loyalty in the Online Transportation
}

\section{Putu Gde Arie Yudhistira*}

Manajemen Bisnis Perjalanan, Sekolah Tinggi Pariwisata Nusa Dua Bali Indonesia

*Corrosponding author’s Email: arieyudhistira@gmail.com 


\section{Research High Iight s}

Online transportation in Indonesia is experiencing rapid growth. The existence of online transportation is not only in big cities, but has begun to spread to areas that can be categorized as second cities, including Denpasar City as the provincial capital of Bali. Increasingly intense competition, especially in the field of online transportation, where many producers are involved in fulfilling the needs and wants of consumers, causing each service company to place customer satisfaction orientation as the main goal to win the competition. This study aims to determine the effect of service quality offered by online transportation to customer satisfaction in Denpasar City, with the number of respondents as many as 100 respondents. This research is a quantitative descriptive study and the method of this research is a survey method with a questionnaire instrument. The results of the study influence the quality of service on customer satisfaction by $43.5 \%$ while the remaining $56.5 \%$ can be explained by other causes not examined in this study.

\section{Research Objectives}

Service Quality is an activity carried out in order to meet the needs and expectations of customers. Service Quality is the most important thing that needs to be considered in providing services to customers (Kotler \& Keller, 2012). According to (A. Parasuraman, 1998) the concept of service quality that is expected and felt is determined by the quality of service. The quality of service consists of responsiveness, assurance, physical evidence, empathy and reliability. Every consumer wants to get the best service from companies that offer services to them, with good service from service providers then consumers will feel satisfied. Satisfaction felt by consumers makes consumers want to continue to use these products or services in the long run. The company is required to provide good quality service to every customer. Satisfaction is the customer's evaluation of a product or service in terms of whether that product or service has met their needs and expectation (Zeithaml, 1990). The purpose of this study is to prove the hyphotesis H_1: There is an effect of service quality on customer satisfaction. The case study was conducted on online transportation consumers in the Denpasar City. 


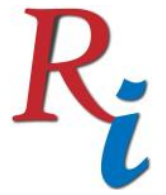

Asia Proceedings of Social Sciences

(APSS)

www.readersinsight.net/APSS

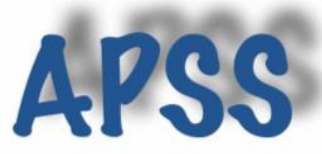

\section{Methodology}

The study uses two variables, the service quality variable consisting of five indicators (tangible, reliability, responsiveness, assurance, and empathy) (A. Parasuraman, 2001) and customer satisfaction variables which consist of five indicators (product quality, service quality, emotional, price, and cost) (Swastha \& Irawan, 2005).

The research conducted is descriptive and quantitative research, the method in this study uses survey methods with questionnaire instruments and data analysis techniques using multiple linear regressions.

The data source used is primary data through questionnaires about how the level of customer satisfaction in using online transportation facilities in Denpasar City, involving 100 respondents to customers of online transportation services.

\section{Results}

Based on the data processed, the results of linear regression analysis in this study get the results using software SPPS Statistics version 20. This analysis is used to measure how the level of contribution of the independent variable (service quality) to the dependent variable (customer satisfaction).

Based on the results, the regression equation form is as follow below:

$\mathrm{Y}=5,197+0.309 \mathrm{X} 1+0,134 \mathrm{X} 2-0,136 \mathrm{X} 3-0,419 \mathrm{X} 4+0,041 \mathrm{X} 5+0,565$

It is known that the value of $\mathrm{R}=0.660(66 \%)$ showed that the relationship between variables quality of service with customer satisfaction is strong. And the coefficient of determination $\mathrm{R} 2=0.435$ shows that service quality indicators ( $\mathrm{X}$ variable) affect customer satisfaction ( $\mathrm{Y}$ variable) by $43.5 \%$, and the remaining $56.5 \%$ is another factor that influences customer satisfaction not examined in research.

It is known that service quality indicators that affect Customer Satisfaction are service Quality Indicators whose results are under 0.05, that are Tangible with the results of 0.031 and Assurance Indicators with a result of 0.022 . 


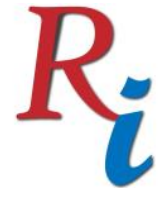

Asia Proceedings of Social Sciences

(APSS)

www.readersinsight.net/APSS

\section{Findings}

The study shows that the correlation analysis ( $\mathrm{R}$ ) between service quality variables and customer satisfaction variables was included at a strong level. Because the value of $R$ is positive, the effect of service quality on customer satisfaction is positive.

The results of the determination coefficient (R2) of service quality factors with indicators of tangible, reliability, responsiveness, assurance and empathy affect customer satisfaction using online transportation services in Denpasar City and the rest are influenced by other factors not examined in this study. Then further research is needed to find out other factors that influence the results of this study.

\section{References}

A. Parasuraman, V. A. Z., Leonard L. Berry. (1998). SERVQUAL : A Multiple Item Scale For Measuring Consumer Perception Of Service Quality. $64 \quad 1, \quad 1237$. https://www.researchgate.net/

A. Parasuraman, V. A. Z., Leonard L. Berry. (2001). Delivering Quality Service (Sutanto, Trans.). New York: The Free Press.

Kotler, P., \& Keller, K. L. (2012). Marketing Management. 14th Edition. New Jersey: Prentice Hall.

Swastha, B., \& Irawan. (2005). Asas-asas Marketing. Yogyakarta: Liberty.

Zeithaml, B. (1990). The Concept of Customer Satisfaction (Purwoko, Trans.). USA: The McGraw-Hill Companies. Inc. 